\title{
A Litany of Saints: Remembering the Early Years of HIV/AIDS Activism in the First Year of a New Pandemic
}

https://doi.org/10.51897/interalia/UBQQ8712

\author{
Mary C. Foltz \\ Lehigh University \\ Adrian Shanker \\ Bradbury-Sullivan LGBT Community Center \\ Liz Bradbury \\ Bradbury-Sullivan LGBT Community Center \\ Kristen Leipert \\ Bradbury-Sullivan LGBT Community Center
}

With the emergence of COVID-19 in the U.S., many LGBTQ people found ourselves reflecting upon the early years of HIV/AIDS and how our communities responded to the lack of robust federal and state response to this preceding public health crisis. As the leaders of the Bradbury-Sullivan LGBT Community Center (BSC) in eastern Pennsylvania became a central resource for our community sharing up-to-date information about COVID-19 and organizing vaccine clinics, they also recognized the historic nature of this moment as many elders in our community consistently tried to make sense of the current crisis by contemplating their past AIDS activism and organizing. In March of 2020, BSC staff and archivists received grant funding to conduct an oral history project called "40 Years of Public Health in the LGBTQ Community: Collecting and Curating Local LGBTQ Health Experiences From HIV/AIDS to COVID-19," which recorded both timely commentary on the impact of COVID19 on LGBTQ people and memories of HIV/AIDS organizing that seemed urgent and relevant to our contemporary moment. Offering excerpts from oral histories collected in 2020, this piece explores how COVID19 spurred LGBTQ people in the Lehigh Valley to share stories about communal grief, health inequity, political responses to pandemics, and organizing to support the health of minoritized communities.

Keywords: COVID-19, HIV/AIDS, oral histories, LGBTQ community archives

In March of 2020 during the emergence of COVID-19, LGBTQ elders in Pennsylvania's Lehigh Valley, like LGBTQ people in other communities, were haunted by memories of the 1980s when HIV/AIDS decimated friends, chosen family, and lovers. As President Trump spread false information about the virus and bungled the federal response, elders recalled the era of Ronald Reagan and his murderous silence and inaction as gay men, bisexual men, and trans people died. While the two viruses and activist responses were different, the desire for accurate information from medical professionals about the spread of COVID-19 stirred up memories about early responses to HIV, some blistering with homophobia and others providing necessary information to communities about transmission 
and treatment. For many elders, there were eerie similarities between the 1980 s and today as governments in both periods ignored the needs of minoritized communities in response to deadly viruses; as Black, Latinx, and Indigenous communities faced higher death rates from COVID-19, elders recalled the challenges faced by QTPOC during the early years of HIV and how homophobia and racism inspired widespread disavowal of national and international responsibility to attend to HIV+ people, to invest in research, and to share information about transmission. When The New York Times showed that the price of inequality is death in multiple stories about COVID-19's impact on Latinx, Indigenous, and Black Communities ${ }^{1}$, QTPOC in the Lehigh Valley concurred as some lost multiple family members to the recent virus. And all of our diverse elders could remember funeral after funeral of beloved friends from decades before when homophobia, transphobia, and racism shaped the lack of quick response to HIV; then, too, the price of inequality was death although news media in the early years tended to ignore the crisis or to allow homophobia to shape coverage ${ }^{2}$. In their isolation, their current grief resonating with histories of loss, our diverse elders ached to speak with each other and with younger generations about what they had survived and those who didn't, how early generations responded to HIV and what strategies we might deploy this time around with a new pandemic. They wanted to share reflections about the import of community responses and organizations to addressing inequity in healthcare and fighting for the lives of each other in the face of callous governmental indifference and spread of misinformation across the national stage. They wanted to speak of the absolute necessity of clinging to each other in hyperlocal responses to those suffering in our communities even as we struggle for competent federal and state response to health crises. And from quarantine, they needed an outlet.

Bradbury-Sullivan LGBT Community Center in Allentown, PA recognized this need early in the COVID19 pandemic ${ }^{3}$. As our region's central LGBTQ organization, they are on the front lines, advocating for LGBTQ health equity in our region. While some of their work focuses on health promotion and advocacy, they also create programs that celebrate regional LGBTQ arts and history. In 2016 they established the Lehigh Valley LGBT Community Archives in partnership with Muhlenberg College 4. The archive collects and preserves materials from local LGBTQ organizations, leaders, and community members to support robust historical accounts of our community's history. While center staff worked

${ }^{1}$ For a discussion of the impact of COVID-19 on Latinx communities, see Fink (2021); and Jordan and Richard A. Oppel, Jr. (2020). For a discussion of the impact on both Latinx and Black communities, see Oppel, Jr. et al. (2020) and Santos (2021). For a discussion of the impact on Indigenous communities, see Healy (2021) and Conger et al. (2020).

2 For information on how news media covered HIV/AIDS in the 1980s and 1990s, see Treichler (1999); Watney (1997); and Kinsella (1992). For recent journalistic reflection on The New York Times coverage of HIV/AIDs, see Soller, ed. (2018).

3 To learn more about Bradbury-Sullivan LGBT Community Center, visit https://www.bradburysullivancenter.org/.

${ }^{4}$ The Lehigh Valley LGBT Community Archives were created in partnership with Muhlenberg College; while BradburySullivan LGBT Community Center maintains ownership of the archives, Muhlenberg generously provides space for the collections and archival assistance in processing, digitizing, and managing the collections. This unique partnership ensures that the local LGBTQ community has access to collections to which they have contributed, as well as oversight over their use and development, even as Muhlenberg College offers resources to ensure safe preservation and expert archival processing and organization. To peruse the collections in the Lehigh Valley LGBT Community archive, visit https://trexler.muhlenberg.edu/library/specialcollections/collections/\#lgbt. 
with speed to share information about COVID-19 prevention for the LGBTQ community, they also recognized the historical import of this significant moment in time and the urgency of collecting life histories of elders in our community as they are especially at risk from this virus. Expanding from a previous oral history grant, center staff quickly applied for and received grant funding to conduct interviews with diverse community members to collect their thoughts about the recent pandemic and recollections of the early years of AIDS activism in the Lehigh Valley. While we are inspired by a number of oral history projects created in metropolises like the groundbreaking ACT UP Oral History Project coordinated by Jim Hubbard and Sarah Schulman ${ }^{5}$, we also agree with a number of LGBTQ historians that more work needs to be done in small urban centers and rural communities to collect the unique histories of LGBTQ people outside of New York City, San Francisco, and Los Angeles ${ }^{6}$. Our archival projects, like those produced in other small urban centers and rural communities, are important contributions to expanding our understanding of LGBTQ history.

In this short piece, we share a few excerpts from oral histories included in the collection titled 40 Years of Public Health in the LGBTQ Community: Collecting and Curating Local LGBTQ Health Experiences From HIV/AIDS to COVID-197. We hope to highlight here how leaders of a community in a small urban center were prompted by COVID-19 to reflect upon communal grief, health inequity, political responses to pandemics, and organizing to support minoritized communities. We believe that oral history collection and curation through public programs are powerful ways both to honor the value of our elders' contributions to social change in our region and to create intergenerational conversation that can fuel on-going political struggle for equity for LGBTQ people. With this particular project, we hoped to instigate conversations in our own community about knowledge produced during healthcare crises and strategies utilized in the early years of AIDS that might be useful today. Even as we certainly focused upon stories about effective regional AIDS organizing that administered to the dying, shared information about transmission and HIV, and advocated for HIV+ people with political campaigns and outreach to healthcare organizations, we also wanted to build a space for our community to grieve, to commemorate, and to name those that we lost to AIDS and those that

\footnotetext{
${ }^{5}$ To access the ACT UP Oral History Project, visit http://www.actuporalhistory.org/index1.html. For other impactful oral history projects focused on HIV/AIDS, see University of California San Francisco's AIDS Oral History Project (https://www.library.ucsf.edu/archives/aids/); University of California Berkeley Library's AIDS Epidemic in San Francisco oral history project (https://www.lib.berkeley.edu/libraries/bancroft-library/oral-history-center/projects/aids); and the GLBT Historical Society's San Francisco ACT UP Oral History Project (https://www.glbthistory.org/oral-history-projects).

${ }^{6}$ A number of LGBTQ studies scholars expand beyond a limited focus on coastal metropolises as they turn to lesser studied urban centers and rural communities. In Pennsylvania, our archival team has benefitted from the work of the LGBT Center of Central PA History Project (https://centralpalgbtcenter.org/lgbt-history-project) as a model for community-based archival collection and exhibition. For a rich discussion of Central PA LGBT history based on this project, see Burton and Loveland (2020). Other recent monographs also address LGBT archives and archival projects outside of New York City, Los Angeles, and San Francisco. See Kumbier (2014), especially Kumbier's discussion of archival projects focused on Drag King communities in New Orleans (121-152). For a discussion of Sacramento's Lavender Library, Archives and Cultural Exchange (LLACE), see Diana K. Wakimoto et al. (2013). For discussion of rural LGBTQ communities, see Gray et al. (2016); Johnson (2013); Herring (2010); and Gray (2009).

${ }^{7}$ To see the full interviews from this collection, visit this page.
} 
we lost so recently in the past year. And we wanted to acknowledge the caretakers and organizers in our community, the ones who carry the fire, as they shine a light on inequity then and now, fueled by their grief and rage to fight for social change. For this issue of InterAlia: A Journal of Queer Studies, we offer community reflections on mourning, politics, and inequity to center non-academic voices in the journal's current focus on LGBTQ communities and pandemics. We hope that these excerpts might inspire academics and non-academics outside of major urban metropolises to build their own LGBTQ oral history archives that share overlapping and divergent stories about your communities' history, including life stories about how LGBTQ people organize locally to address inequity in healthcare.

\section{On Mourning}

Many of the oral histories in our collection touch on the magnitude of loss from AIDS and the continuation of grief across decades, which rose again with force as the death tolls of COVID-19 emerged in media outlets. General statements that list the numbers of funerals attended in the $80 \mathrm{~s}$ and $90 \mathrm{~s}$ are spiked with clear recollections of lovers and friends offered with vivid detail. So, too, some community members reflect upon recent familial and community losses from COVID-19, specifically addressing the high-rates of deaths within Black and Latinx communities and the challenges of being essential workers. The following excerpts offer a few stories about what one community member, $\mathrm{T}$. Scott Allen, calls "a litany of saints."

$[Y]$ ou were looking at death to be. And [...] you just knew, because back then, you know, there were no cocktail drugs. I mean, you know, you weren't going to slow it down. It was going to take its course. And, you know, it was a one-way ticket and it was a very short runway. And then you would see them the next week, and then they could barely walk. I remember one dear friend of mine who passed away, probably no older than age 27 maybe at the oldest, you know, walking his mother across 9th Street to go to bingo one night. And this was a party boy. This was a boy who was out every night - party, party, party, party. And now his skinny little legs were walking with his mother, taking her to a bingo game. You know, what a 180 that was. And, sure enough, you know, I was by his bedside, and helping him eat. [...] And it actually was a dark era, quite honestly. I mean, death was a regular part of the conversation. [...] [Y]ou would look in the obits, and, 'Oh, John died. Mark died. Fred's dead.' [...] I mean it was a litany of saints.

-T. Scott Allen (2020)

And my first encounter with somebody who was HIV + was a gentleman by the name of Chuck, who has passed on. [...] And we ran into him in Atlantic City [...] [and] he was coming out of a bar and we were going in, my late husband Will and I. And he looked really - he had all these black and blue marks all over him, which was Kaposi sarcoma and I didn't know that at the time. [...] And I would say maybe 
six months later, they were doing a fundraiser for him to help with the medical bills for him. So, we went down to that. [...] Chuck was a wild child when I met him. And I had seen him several years over, you know, over the years. I mean I knew him before I met Will. So, we had gone out several times and were, you know, intimate. But that was the last time that I had seen him, down in Atlantic City.

-David Moyer (2020)

[I]t became an era that was, you know, death and obits, and people we knew were dying off. And you would go to the bar and you would see people one week and [...] next week they wouldn't be there. [...] [A]nd then you read the paper two weeks later - they're dead. And that sort of brings me to my personal story [...] in '86 is when I met my partner, Jim. And he was a specialty nurse - a high-end nurse - in the hospital. And we had a wonderful life together. And then he was working a lot of overtime, a lot of twelve-hour shifts, a lot of back-on-back shifts over weekends and then he was losing his appetite - and he was thin to begin with - but he was losing some weight. [...] And then he got a rash, and he couldn't get rid of this rash. And he went to the dermatologist. And along the road, he gets an HIV test. [...] And I can clearly remember - it was just before Thanksgiving in 1990, I came back and [his] test was positive. Based on his T-cell count, which was very, very low, they surmised that he got infected before he and I met, somewhere in his prior journeys. And Jim was very young. I mean at the time he was probably 27 , maybe 28 . So that was around Thanksgiving and Christmas time [...] and by July - July 9th, actually [...] he passed away.

-Charles Versaggi (2020)

I personally have lost three people in my family to COVID. The realities for minority communities. [...] Black communities, you know, those numbers that were coming out from the Black community about the spread of COVID, they weren't false statistics. The Black community has been hit really hard by COVID. [...] [My husband and I are] both essential workers. My husband is the hardest working guy I know. [...] And he was working for another company in the Lehigh Valley. [...] And when COVID first hit, the company didn't seem to be taking it seriously. And you know they were starting to get cases in the warehouses but they weren't reporting them. They weren't telling the employees that they were getting cases. [...] So, he moved to another warehouse [...] [and] they're taking everything seriously. [...] [W]e both realize that because we both have to go out to work, him more than me, you know, he realizes he's exposed, even with all the protection that they can give.

-Brian Jones (2020) 


\section{On Politics and Pandemics}

One theme that community members addressed in their interviews was an eerie feeling of similarities between political responses to AIDS and political response to COVID-19. Even as they noted clear differences between historical periods as homophobia and transphobia shaped political indifference and callousness in the 80s and 90s, they made comparisons between the Reagan and Trump eras, noting federal and state ineptitude that magnified the suffering of the ill and dying. The silence of Reagan era politicians about AIDS and a willful lack of funding and coordinated attention to the disease was analyzed in relation to the brash trumpeting of misinformation and downplaying of the seriousness of COVID-19, especially for minoritized communities, by Trump. For our community, reflections on inept political responses across historical periods bled into thoughts about the role of conservative religious organizations in promoting misinformation during the COVID-19 pandemic.

The problem we have in this culture, and it happened with HIV and AIDS too, is things get politicized right away. It's like you're a red state; you don't wear a mask. It you're a blue state, you wear masks. Well, that's ridiculous. And Ronald Reagan you know how he was. Ronald and Nancy? They didn't want anything to do with AIDS/HIV.

-T. Scott Allen (2020)

It's such a different situation now than the AIDS crisis was. But, at the same time, there are a lot of parallels that we see and one of the things, if we as the gay community hadn't kind of taken hold of it ourselves, it would have been left to just run rampant, you know what I mean? We weren't getting support from the, you know, Reagan/Bush government. We weren't getting support by a lot of people in general because they thought this was a gay disease. It was only affecting gay people and it was only affecting drug users, so better to it. [...] But one of the parallels I see to this and our situation now is actually the way that a lot of people in the government are trying to make it seem as if it's a non-issue, it doesn't exist, you know? We can look the other way, it'll just go away, you know? And that, we saw when we had the AIDS epidemic. It was, like this is a small, isolated thing. It's only affecting, you know, this type of people. It's nothing for us to worry about [...] until it started going into the population as a whole and heterosexual couples had to worry about it, too, and it was like this is something that could spread that way. [...] Had AIDS been only affecting rich, white businessmen, they would have had funding a lot quicker. [...] But I didn't really notice a feeling of support or denial or anything like that coming from the government. It almost felt, to be honest with you, back then, it felt like this was our problem, we had to take care of it. Nobody else cares, nobody else is even looking at it, and so if anything's going to be done, we have to do it as our own community.

-Mitch Hemphill (2020) 
Well, I think what strikes me about it, going to the politics of it all, is that like HIV/AIDS, there was no recognition of it at the top. So we didn't have like a national focus on, hey, let's take care of this, together as a nation. Took a while, and I think the passage of Ryan White money was key, that there were some people in legislature who got it, and they got it usually because they had a child die, or they knew someone. [...] [And] I think that's been certainly one of the issues with COVID. [...] Now what I think is a little different, or maybe it's not different, I don't know, but we learned everything medically or otherwise from each other and from people who had just had it. And I think now with COVID, [...] I mean if you have half a brain, you could see that this was going to go to other places, you know. Everyone was susceptible. [...] But I think not having the top political support has been a problem. -Rose Craig (2020)

How did this happen and how do we have such ineptitude in our systems and things that should be dealing with this stuff and the anger of the ignorance of people? Of the lack of empathy and compassion. [...] So, the number of people who during this pandemic that have just decided that selfishness is the way to go. That not being concerned about the other person is good. [...] [A]nd I work in the Church community. [...] And, you know, MCC Lehigh Valley is a very progressive, inclusive congregation. But I can tell you that from - in the Church world, [...] Church universal not MCC Lehigh Valley but just Church Universal, you know, you got some wing bats. You got a lot of them who, for some reason, they can't deal with science, they can't deal with just the realities of how the world works because its' contrary to what a book says. [...] I firmly believe that a lot of this insanity that we're dealing with - my grandmother used to tell me that Church folk are the worst folk. (Laughter) And I've worked and been in the Church all my life and I agree with her. So, a lot of what we are dealing with in this country, in this Christian country - if we didn't have so many self-righteous religious folk, we might be in a better situation. [...] And I think [...] things we're lucky about in our community and in our Lehigh Valley and also in the whole state of Pennsylvania is we have a wonderful Secretary of Health in my opinion. [...] I mean, to have Dr. Rachel Levine speaking as a trans woman but also speaking as the incredible voice of science and reason.

-Brian Jones (2020)

\section{On Inequity and Organizing Communities of Care}

Throughout many interviews, narrators returned again and again to the absolute power of community responses to HIV/AIDS. In response to governmental inaction and grief in the face of so much death, local community activists started the AIDS Service Center as a hub for education, fundraising, and direct services for those dying from and living with HIV. So, too, they created an educational organization called Fighting AIDS Continuously Together (FACT) . LGBTQ community 
members in larger regional health organizations, like the Allentown Health Bureau, became key players in bridging activist organizations and civic public health initiatives to support HIV+ people. Church leaders, especially in the regional Episcopal Church, also became activated to address phobic religious communities' responses to HIV/AIDS and to create loving community spaces to administer to the spiritual needs of community members. Finally, community members started regional LGBTQ publications with the specific aim of sharing information about HIV and promoting the work of our regional activists. All of the interviews excerpted below show the value of community engagement in public health initiatives. And these people in particular have laid the foundation for our community's current responses to COVID-19 as our LGBTQ organizations have been a source for accurate information and informed education about the virus, and advocacy for LGBTQ people's health in Pennsylvania during the pandemic. Their stories also serve as a challenge to think holistically about how to support the overall health and well-being of our community, including thinking beyond access to healthcare and education about viruses to housing and food insecurity brought on by and preceded by the recent health crisis.

We were beginning to have so many people that we socialized with all the time getting ill that suddenly there were not so many more parties, frankly, but it was mostly, okay, how do we help our friends? [...] So, I proposed that we, instead of being a [LGBTQ] community center, we change ourselves to being a service center. [...] [W]e dissolved the community center and we began the AIDS Services Center. [...] [W]e had a board of directors; we had everything we needed for the 501(c)3 application, got that approved. Part of my job was to get out there and sell this to the typical regular funders in the community to make them aware of what was going on. Because back then, nobody was really talking about it, especially in Allentown or Bethlehem, or at least in Pennsylvania. And the whole issue about being gay was again something that wasn't a real popular topic. [...] Part of what we provided at that point in time, now there were people in the community, and people associated with us that were really doing the handholding, feeding, taking care of, wiping the behinds of our friends who got ill quickly; there were a lot of angels out there doing that kind of work. And we were associated with that. One of the skills that we could actually bring was the fact that [...] [we] knew how to navigate the system, the human relations system, and the nonprofit system within the Lehigh Valley. And it was important, because part of what we had to do was also educate, to inform the community about what this was, why this was important. [...] At the same time, we went out and hustled money... and wrote grants and did things like that, and also looked for corporate sponsors. [...] [W]e knew that we wanted to add case management, was what we called it at the time, and basically, that was a matter of looking at the person, sort of holistically, and seeing what did they need? Did they need a place to stay? Did they need some nursing care? Did they need food? You know, what was it that each particular 
person needed?[...] [I]t was like, hey, Joe is in trouble; he's down the street. You know, it was a very great network of people who knew people. And you know, again, this all evolved out of our friends dying, and us trying to figure out what the hell can we do [...] and that was the basic reason why it all went that way.

-Rose Craig (2020)

And within our community, we knew that the government wasn't really doing much of anything for it. The health departments weren't doing anything. And to raise awareness and do something about it, we kind of had to do it on our own. And that was one of the reasons, you know, with founding $\mathrm{FACT}$, although it was supporting the entire community, not just gay and lesbian [...] people [...] but it opened itself up, knowing it had to do everything for the entire community and have those services for everyone. That was a big step forward, you know, and drove a lot of things, I think with like the Allentown Health Bureau. [...] The money [from FACT fundraisers] at that point, as I understood it, with my involvement with them, in the beginning, was a lot of it, it had to do with helping people that were HIV-positive. It had to do with educating the public. It had to do with getting materials like condoms out in bars and literature out in bars and making people more aware of it within the community. And, like I said, obviously, they, you know, were open to the entire population of our area. However, that was where the focus needed to be because our community was being affected in a higher ratio than the community at large. So, that's really where their focus was, to educate, to - there was money, as they went down the line, that was made available, like, through grants for different other organizations. So, they're almost, like, a parent organization to other organizations. But the main thing was to get the word out, to get the materials out so that people understood better what was going on and how to help prevent it from spreading.

-Mitch Hemphill (2020)

[I]t wasn't until, well, 1985 is when FACT was started. And, again, it was started by a group of bar owners and local merchants, and people who were - wanted to do something because their friends were dying. And nothing was being done, really, at that point, then, because I don't think the AIDS Activities Office had started yet, [...] and doctors, again, didn't really, still, didn't know what was going on. But so, they held an event up at Rainbow Mountain called the FACT Summer Games. [...] So, I went up the first year by myself and it was overwhelming. I mean, we had there must have been a thousand people there, if not more, back then, in those days.

-David Moyer (2020) 
[U]p until that time when I was [...] hired [at the Allentown Health Bureau] [...] at least in the LGBT community, we were perceived as the health police. You know, if you're going to go to the health bureau and you test positive, look out, they're going to do this stuff. [...] But we don't do that stuff. [...] We're not - that's not what we're about. And I think one thing that helped the LGBT community was that I'm a gay man and I'm doing this work. And that's why I think a lot of - you know, the word got out that way. Hey, we have an advocate in the health department. If you want testing, you can go see him. [...] Or, if you don't want to go in, call and he'll come to your house or apartment. [...] And I would do that.

-David Moyer (2020)

Because there was no safety net from Washington at the time or Harrisburg, really. It was a very hopeful time. While it was sad and this was a tragic thing going on, a lot of innovative things were being done, especially the church had a chance to really be a partner with groups that they wouldn't have had partnerships with otherwise, and make friends, and show them the church wasn't - I mean, it was religious communities weren't all great at the time, as you know. There was a lot of fear in churches. [...] And in our church tradition, communion is so important that we had to do a lot of stuff with the church about communion, about how you couldn't - finally, we got doctors to come out and say, "You cannot get this from the common cough. Period." You can't. Unless you're doing something else at the altar rail besides taking communion, you can't get HIV. (laughs) [...] So one of the big things that we did in the Episcopal diocese that we did ecumenically, actually it wasn't just us, but it was kind of spearheaded by us - but it was the healing. We had that first healing service at the cathedral. [...] We wanted to let people with HIV and AIDS know that we would touch them, that we would actually touch them, that they can take communion with us, and we're not going to be afraid of you, and we want you not to be afraid of us. And so, that was the big message that we were trying to put forth in that service. And I remember that it was packed. I mean, there was not a seat left in the room, mainly because allies - a lot of allies came.

-T. Scott Allen (2020)

But I started Above Ground magazine and launched that in November of 1994. And the reasons for launching the magazine was because LGBTQ - the community in the Lehigh Valley no longer had a periodical [...] and it was something that was needed. It was missing for a period of time. [...] [I]t was an entertainment and information monthly magazine that I put out. And one of the things that I made available through it was access to the HIV/AIDS groups so they could advertise their events, put in articles, you know, different things like that. And I would actually always go to the big events and give them publicity and things like that so people 
kept aware of it. [...] So, that was one way that [information about AIDS and AIDS organizations' events and fundraisers] actually spread throughout the community and into the surrounding areas. [...] So, I hope to think that it did something to help in that way.

-Mitch Hemphill (2020)

To close, this recent oral history project allowed our community to offer up a litany of saints, both those that we have lost in two pandemics and those who rallied to provide comfort to the dying, to advocate for greater information about HIV/AIDS, and to fight for strong civic, state, and federal responses to public health crises. Overall, each interview returned to the import of vital community responses to inequity in healthcare. As T. Scott Allen states in his interview, "And the enemy was multi-fraught. It was prejudice, and discrimination in the culture. It was the medical community and providing services. It was we can't let our brothers and sisters languish. We've got to do something. We can't just sit by and watch this happen. There was a lot of energy around that. [...] But I think more what it taught me was communities can rise up together and address problems that seem insurmountable and seem bigger than us" (2020). The stories shared by our elders give us the ability to see a variety of ways that our community built transformative organizational responses to healthcare crises that can inform our efforts today.

\section{Works Cited}

Allen, T. Scott (2020), interview by Liz Bradbury, Allentown, PA, transcript, "40 Years of Public Health Experiences in the Lehigh Valley LGBT Community: HIV/AIDS", Trexler Library, Muhlenberg College, Allentown, PA, https://trexlerworks.muhlenberg.edu/lgbt_oralhistory/items/show/27.

Burton, William and Barry Loveland (2020), Out in Central Pennsylvania: The History of an LGBTQ Community, University Park, Pennsylvania State University Press.

Conger, Kate, Robert Gebeloff and Richard A. Oppel Jr. (2020), "Native Americans Feel Devastated by the Virus Yet Overlooked by the Data", 31 July, The New York Times.

Craig, Rose (2020), interview by Liz Bradbury, Allentown, PA, transcript, "40 Years of Public Health Experiences in the Lehigh Valley LGBT Community: HIV/AIDS", Trexler Library, Muhlenberg College, Allentown, PA, https://trexlerworks.muhlenberg.edu/lgbt_oralhistory/items/show/30.

Fink, Sheri (2021), "How Covid Overwhelmed One L.A. Hospital in California's Worst-Hit County", The New York Times.

Gray, Mary L. (2009), Out in the Country: Youth, Media, and Queer Visibility in Rural America, New York, New York University Press.

Gray, Mary L., Colin R. Johnson and Brian J. Gilley (eds.) (2016), Queering the Countryside: New Frontiers in Rural Queer Studies, New York, New York University Press.

Healy, Jack (2021), "Tribal Elders are Dying from the Pandemic, Causing a Cultural Crisis for American Indians", 19 January, The New York Times. 
Hemphill, Mitch (2020), interview by Liz Bradbury, Allentown, PA, transcript, "40 Years of Public Health Experiences in the Lehigh Valley LGBT Community: HIV/AIDS", Trexler Library,

Muhlenberg College, Allentown, PA,

https://trexlerworks.muhlenberg.edu/lgbt_oralhistory/items/show/21.

Herring, Scott (2010), Another Country: Queer Anti-Urbanism, New York, New York University Press.

Johnson, Colin R. (2013), Just Queer Folks: Gender and Sexuality in Rural America, Philadelphia,

Temple University Press.

Jones, Brian (2020), interview by Liz Bradbury, Allentown, PA, transcript, "40 Years of Public Health

Experiences in the Lehigh Valley LGBT Community: HIV/AIDS", Trexler Library, Muhlenberg College, Allentown, PA.

Jordan, Miriam and Richard A. Oppel, Jr. (2020), "For Latinos and Covid-19, Doctors Are Seeing an 'Alarming' Disparity", 8 May, The New York Times.

Kinsella, James (1992), Covering the Plague: AIDS and the American Media, Newark, Rutgers University Press.

Kumbier, Alana (2014), Ephemeral Material: Queering the Archive, Sacramento, CA, Litwin Books.

Moyer, David (2020), interview by Liz Bradbury, Allentown, PA, transcript, "40 Years of Public Health Experiences in the Lehigh Valley LGBT Community: HIV/AIDS", Trexler Library, Muhlenberg College, Allentown, PA, https://trexlerworks.muhlenberg.edu/lgbt_oralhistory/items/show/28.

Oppel, Jr., Richard A., Robert Gebeloff, K. K. Rebecca Lai, Will Wright, and Mitch Smith (2020), "The Fullest Look Yet at the Racial Inequity of Coronavirus", 5 July, The New York Times.

Santos, Fernanda (2021), "Life, Death and Grief in Los Angeles", The New York Times.

Soller, Kurt (2018), "Journalists on the Paper's History of Covering AIDS and Gay Issues", The New York Times.

Treichler, Paula A. (1999), How to Have Theory in an Epidemic: Cultural Chronicles of AIDS, Durham, Duke University Press.

Versaggi, Charles (2020), interview by Liz Bradbury, Allentown, PA, transcript, "40 Years of Public Health Experiences in the Lehigh Valley LGBT Community: HIV/AIDS", Trexler Library, Muhlenberg College, Allentown, PA, https://trexlerworks.muhlenberg.edu/lgbt_oralhistory/items/show/25.

Wakimoto, Diana K., Debra L. Hansen, and Christine Bruce (2013), "The Case of LLACE: Challenges, Triumphs, and Lessons of a Community Archives", The American Archivist, 76.2: 438-457.

Watney, Simon (1997), Policing Desire: Pornography, AIDS, and the Media, Minneapolis, University of Minnesota Press. 